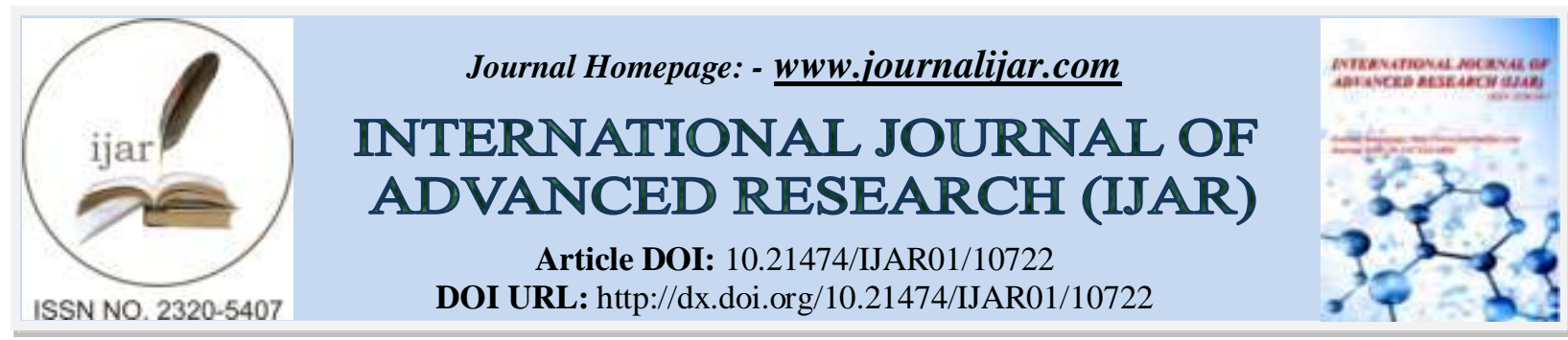

RESEARCH ARTICLE

\title{
THE EFFECT OF SERVICE QUALITY, IMAGE AND TRUST ON STUDENT LOYALTY IN HIGH SCHOOL OF ECONOMIC SCIENCE TRI DHARMA WIDYA, JAKARTA
}

\section{Novi Rakhmiyanti ${ }^{1}$, Prof. Dr. Bedjo Sujanto ${ }^{2}$ and M.Pd, Prof. Dr. Eliana Sari ${ }^{2}$}

1. Students in the Educational Management Doctoral Program, UNJ.

2. Lecturer in Education Management, UNJ.

\section{Manuscript Info}

............................

Manuscript History

Received: 25 January 2020

Final Accepted: 27 February 2020

Published: March 2020

Key words:-

Quality of Service, Image, Trust and Loyalty

\section{Abstract}

This study aims to obtain information about the influence of Service Quality, Image and Trust on Student Loyalty at Tri Dharma Widya High School of Economics. The research was conducted by using survey method with path analysis in hypothesis testing. The population in this study as many as 169 respondents, and a sample of 119 respondents are selected by using random sampling. Research focuses on four aspects; service quality, institutional image, trust and loyalty. Data were collected by questionnaire and analyzed by path analysis. The result of the analysis concludes that (1) there is a positive direct effect of service quality on loyalty, (2) there is positive direct influence of image to loyalty, (3) there is positive direct influence of trust on loyalty, (4) there is an indirect effect of service quality on loyalty through trust (5) there is an indirect effect of image on loyalty through trust (6) there is an indirect effect of service quality on loyalty through image.

Copy Right, IJAR, 2020,. All rights reserved.

\section{Introduction:-}

Nowadays competition in the provision of educational services especially tertiary institutions is increasingly developing, and experiencing continuous metamorphosis. Higher education is an institution providing services in the field of education, although in its operation does not prioritize profit as the main goal, providing excellent service to students is a necessity like a profit-oriented institution. Universities in providing services have special characteristics that cannot be compared to other service institutions outside of tertiary institutions. For example the services provided to students are bound by regulations from higher education and higher education (DIKTI). Higher Education is an institution that plays an important role in the process of developing human resources. Through the education programs of each well-controlled tertiary institution, it is expected that qualified graduates can. The existence of this intense competition requires business operators in the service sector of higher education to create an advantage in competing compared to other business actors.

In the midst of intense competition with many players in the market, customer loyalty becomes a rare item because it is difficult to obtain. This is caused by changes in both the changes in customers (eg, tastes, psychological aspects) and changes in the environment (eg, science, technology, politics, economics, social, culture) that can occur at any time so that it can affect loyalty customers directly or indirectly.

Private universities get a lot of attention both from the community and from the government. This is partly due to the large number of tertiary institutions that do not carry out the tri dharma mission of tertiary institutions 
properly. Even in the implementation of the learning process and teaching was not carried out properly. As a result, not only has the quality of graduates of private tertiary institutions deteriorated, but also the loyalty of students towards private tertiary institutions has declined. One of the private tertiary institutions experiencing this problem is the Tri Dharma Widya School of Economics (STIE TDW), Jakarta.

The tendency of low student loyalty certainly needs to be resolved by the owner, especially the Tri Dharma Widya Foundation. Finding a solution or solving this problem is important so that this High School can continue to grow. Internal improvement at this high school is one way out. Among these internal improvements is to increase the loyalty of existing students. Loyalty according to ODirectr in his book Grigorogis and Siskos (Grigoroudis \& Siskos, 2010) are: " Customer loyalty is deeply held commitment to rebuy or repertoire a preferred product or service consistently in the future, despite situational influences and marketing efforts having the potential to cause switching behavior ".

Loyalty is a strong commitment from the service recipient to buy or have a service or product consistently in the future despite the influence of the situation and marketing efforts of other parties to change the behavior of the service recipient.

Loyalty will be useful not only in the short term, but also in the long term. Consumer loyalty as consumer loyalty to a product, both certain goods and services. Customer loyalty is a manifestation and continuation of customer satisfaction in using the facilities and services provided by the company, and to remain a consumer of the company.

Maintaining student loyalty is a demand that must be implemented immediately because basically with the maintenance of student loyalty, the university will always be maintained for its survival because there are financial resources coming in from students so that loyal students can strengthen sources of institutional funding. Another advantage of loyal customers is satisfied customers and loyal customers will refer the company and existing products to people they know.

As stated by Frederick F Reicheld and Steven M Ramsay, (Ramsey, 1988)" Customer loyalty is a customer willingness to continue patronizing a firm over the long term, purchasing and using its goods and services on a repeated and preferably exclusive basis, and recommending the firms products to friends and associates.

Students who are loyal will tend to re-use educational services and also carry out promotional activities to recommend those closest to them to become students in college. There are several factors that are thought to affect loyalty. First factor, service quality. Excellent service quality, in the sense that it can meet student expectations will bring satisfaction among students which will have an impact on loyalty among students by not moving to other tertiary institutions. Annamdevula and Bellamkonda 4 research (Annamdevula \& Bellamkonda, 2016) in a journal entitled "The effects of service quality on student loyalty: the mediating role of student satisfaction", states that service quality is a key antecedent to students' satisfaction and loyalty. The best service satisfy students inturn make students loyal to the institution.

Loyalty is the key in the theory and practice of marketing services that are believed to be a way to realize long-term goals by prioritizing values that provide satisfaction and return to use these services, recommending others, maintaining good name, spreading positive things, and improving the quality of each customer so that they become loyal consumers. ODirectr in Hurriyati (Grigoroudis \& Siskos, 2010) said: Customer loyalty is deeply held commitment to rebuy or repertoire a preferred product or service consistently in the future, despite situational influences and marketing efforts with the potential to cause switching behavior .

Mowen and Minor (Minor, 2002) revealedCustomer loyalty is defined as a degree to which a customer holds a positive attitude to the word product, has a commitment to it, and intends to continue purchasing it in future. Customer loyalty is directly influenced by the quality of service or satisfaction with the product that has accumulated over time as well as the quality of the product quality.

Sheth and Mittal in leonard (Sheth and Mittal in leonard) stated Consumer loyalty is consumer commitment towards a particular brand, store or retailer, shown by very positive attitude and reflected by a consistent purchase behavior (Leonard, 2013) loyalty is the consumer's commitment to the brand, certain stores or retailers, shown by a very positive attitude and reflected by consistent buying behavior. 
The same thing also expressed by Grembler in Leonard et al (Leonard, 2013) related to loyalty, consumer loyalty is an extent shown by the customer in repurchases behavior, a positive attitude towards service providers and a tendency to use services from the same company when there is an urgency to fulfill.

Quality is a dynamic condition related to products, services, people, processes, and the environment that meets or exceeds expectations. According to Feigenbaum, " quality is full customer satisfaction " quality is fully customer satisfaction (Leonard, 2013). This opinion shows that a product is said to be of quality if it can give full satisfaction to consumers, that is in accordance with what consumers expect of a product.

Service is an action or activity offered by one party to another party which is basically intangible and does not result in any ownership.

According to Lovelock \& Wirtz (Christopher H. Lovelock, 2012) the services are: Services are economic activities offered by one party to another. Often time-based, performances bring about desired recipients, objects, or other assets for which purchasers have responsibility. In exchange for money, time and effort, service customers expect value from access to goods, labor, professional skills, facilities, networks and systems; but they don't normally take ownership of any of the physical elements involved.

Services are economic activities offered by one party to another party. Often time-based, performance that brings results that customers want or on objects, or on other assets that buyers want. In exchange for money, time, and effort, customer service provides access to goods, labor, professional skills, facilities, networks, and systems, but generally does not take ownership of any physical elements involved. This means that service is every action or performance offered and desired by the customer. At service companies, customers gain access to goods, labor, professional skills, facilities, networks, and systems, but all of these do not usually result in a shift in ownership of the physical elements used.

Quality is a dynamic condition that is a dynamic condition that affects products, services, people, processes and environments that meet or exceed expectations. Service is any action or activity that can be offered by one party to another party, which is basically intangible. Clark (Clark, 1992) revealed that service quality is how consistently the product or service deDirectred meets or exceeds the customer's (internal or external) expectation and needs. "

David L. Goetsch and Stanley B. Davis (Davis, 2010) stated " quality is in the eye of the beholder". Which means quality depends on the person who sees it. This shows everyone has different perceptions of service quality in accordance with their expectations.

Basic service to consumers is to provide customer experience exceeds expectations and maintain relationships with consumers, this is confirmed J. Goodman (Goodman, 2015): "service quality is define as customer service as vital to the end to the customer experience and this to the customer relation ". This means that the quality of service is an important thing in providing consumer experience exceeding consumer expectations and maintaining good relations with consumers. This is because the quality of service will have an impact on customer loyalty. In higher education the quality of services provided will have an impact on students on these tertiary institutions. Loyal students will be a very valuable asset for universities, because students will be willing to promote their universities to others, provide positive feedback, reduce the influence of attacks from competitors of similar institutions and improve the image of the institution.

In the context of the business world, the image needed by the company to be able to survive and excel in the face of intense competition and a dynamic and always volatile business environment . In addition, the company must offer something different and special to the products and services it does to satisfy its customers. Image is the impression that is thought and known by a person or group about something, both the company and its products obtained through experience. Kotler in Ahmad (Ahmad, Ramayah, Halim, \& Rahman, 2017) said, image is the set of beliefs, ideas and impressions a person holds regarding an object. Image is a set of beliefs, ideas and impressions held by someone about an object.

The same thing was expressed by Aaker in Bucheri Alma (Alma, 2014)

states " image is the general impression of what a person or group of people think or know about an object. Image is the overall impression that is in someone's mind about an object. 
A company's image cannot be engineered, meaning that the image does not come by itself but is shaped by the community, from communication efforts and company openness in an effort to build the expected positive image. Newson et al in (Leonard, Mcomm, Heny KS Daryanto, Dadang Sukandar, Eva. Z. Yusuf The Loyalty Model of Private University Students, Study Case: STIKOM London School of Public Relations, International Journal of Information Technology and Business Management 29 th December 2013 Vol.20 No.1, 2012-2013 JITBM \& ARF All rights reserved) states the image is an impression of a person or society towards people, corporate or institution. Image is the impression of a person or society towards a company or institution. For that the company must build a positive image in the eyes of customers in order to leave a positive impression on customers so that a good company image is formed in the eyes of customers.

The effort to build an image is a long process. Because images are all perceptions of objects formed by consumers by processing information from various sources all the time. As stated by Assael in Bucheri Alma states "image is total perception of the subjects that is formed by processing information from various sources over time . (Alma, 2014) Image is all perceptions of objects formed by consumers by processing information from various sources all the time.

Dowling in Van Riel (Fombrun, 2007) states that image is " image is the total impression (beliefs and feelings) of an entity (an organization, country or brand) makes on the minds of people. The meaning of image is the overall impression (beliefs and feelings) of an element (organization, country or brand) that exists in a person's mind.

Trust is the customer's confidence in the service provider that the service provider can be trusted and relied upon. Trust is basically a belief in someone's words and actions. (Greenberg and Baron: 2005) states, trust is a person's degree of confidence in the words and actions of another. Trust is a person's level of confidence in the words and deeds of others.

The same thing was expressed (George and Jones, 2002) said trust an expression of confidence in another person or group of people that you will not put at risk, harmed or injured by actions. Trust is a belief in a person or group that is believed to not be at risk, danger or injury from their actions. Understanding of trust in the above definition states that in trust there is confidence in the existence of certainty or guarantee of a person who is trusted will not cause the person who gives the trust to be in uncertainty or danger.

(De Janasz, Dowd, and Schneider, 2009: 33) sayTrust is a multifaceted concept that captures one's faith or belief in the integrity or reliability of another person or thing. Simply put trust means confidence when you trust people, you have confidence in them-in their integrity and in their abilities .

Trust is a customer's belief that service providers can be trusted and relied upon. Customer trust is a strong adhesive to the continuity of relationship with the company in the long run. Customers who trust the company will tend to be loyal towards the company. Research MComm (In Davis, D. L. G. \& S. B. 2010), entitled The Loyal Model of Private University Students, uses indicators 1) integrity / integrity 2) comprtence / competence 3 ) consistency / consistency 4) benevolence / virtue 5) openness / openness to measure trust the results of research prove that trust has a positive effect on customer loyalty. Thus if the service provider wants to increase customer loyalty the service provider must increase customer trust by increasing integrity, competency, consistency, virtue and openness.

\section{Research Methods:-}

This research uses a quantitative approach with a survey method. This method is to study large and small populations by selecting and reviewing selected samples from the population. Based on data, facts or information obtained through surveys can then be described the condition of each variable and can be influenced by one variable with another variable. In this study to determine the effect of service quality, image and trust on student loyalty at the Tri Dharma Widya School of Economics.

\section{Results and Discussion:-}

The test aims to answer the hypothesis investigators (direct influence) where in a nalisis track to answer the hypothesis of the study conducted by carra calculate beta coefficient (lines), and followed by t test to answer the magnitude of the effect (path coefficients) obtained significant. In this study there are 6 research hypotheses that can be seen in the following constellation model images: 


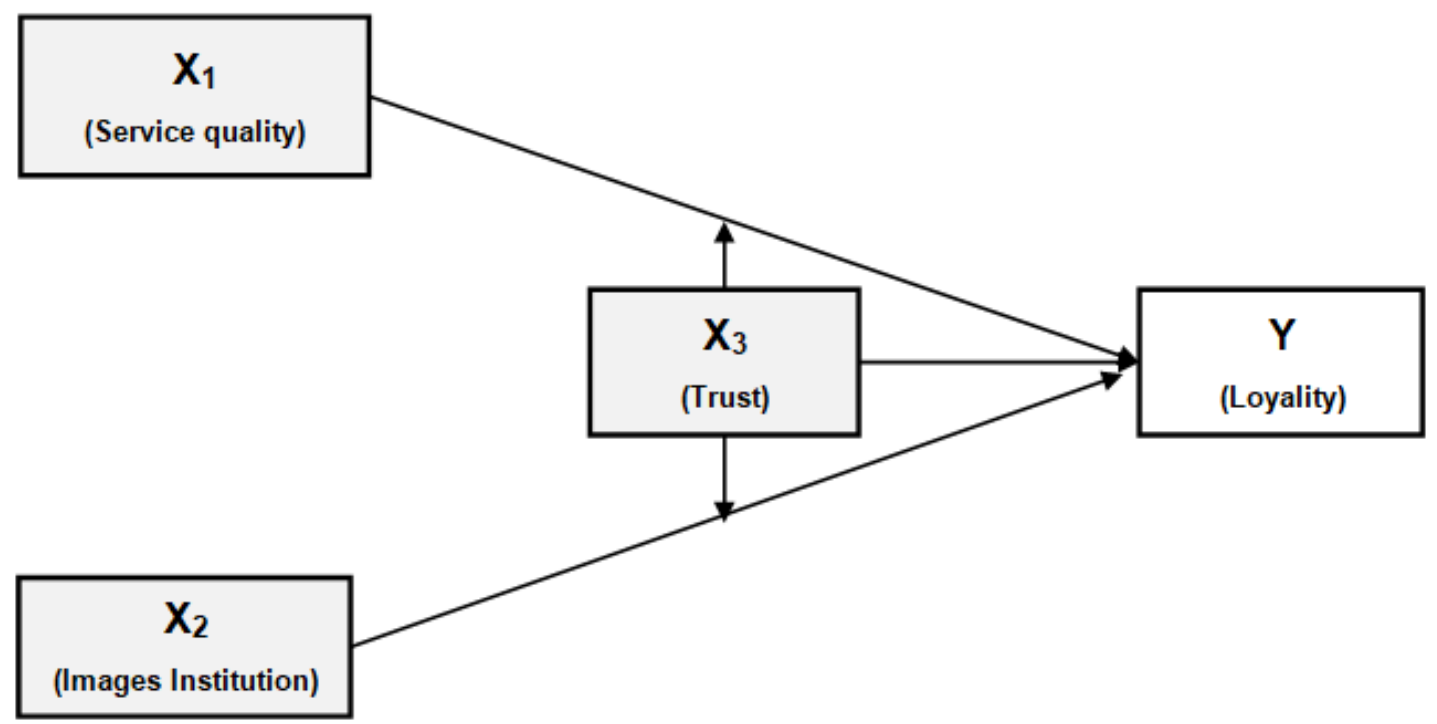

Figure 1:- Research Constellation Models.

Before carrying out calculations to test the causality model using the path analysis model, one must first meet the necessary requirements. One important requirement and must be fulfilled is the path coefficient must be significant for each lane. The next test is testing of the six proposed hypotheses.

\section{Model testing:}

Structural path coefficient 1:

Table 1:- Path coefficients and Structure Significance Tests 3.

\begin{tabular}{|c|c|c|c|c|c|}
\hline Influence & Coefficient & \multirow[t]{2}{*}{ dk } & \multirow[t]{2}{*}{$\mathbf{t}_{\text {count }}$} & \multicolumn{2}{|l|}{$\mathbf{t}_{\text {table }}$} \\
\hline Direct & Pathway & & & $\alpha=0.05$ & $\alpha=0.01$ \\
\hline $\mathrm{X}_{1 \text { with }}$ respect to $\mathrm{Y}$ & 0.268 & 115 & 3.19 & 1.98 & 2.62 \\
\hline $\mathrm{X}_{2 \text { with }}$ respect to $\mathrm{Y}$ & .244 & 115 & 2.90 & 1.98 & 2.62 \\
\hline $\mathrm{X}_{3 \text { with }}$ respect to $\mathrm{Y}$ & 0.306 & 115 & 3.72 & 1.98 & 2.62 \\
\hline
\end{tabular}

Information:

Significant $\left(\mathrm{t}_{\text {count }}>\mathrm{t}_{\text {table }}\right.$ at $\left.\alpha=0.05\right)$

Very Significant ( $\mathrm{t}_{\text {arithmetic }}>\mathrm{t}_{\text {table }}$ at $\alpha=0.01$ )

From the path coefficient table, the analysis results obtained the path coefficient value $\mathrm{p}_{\mathrm{y} 1}$ of 0.268 and $\mathrm{t}_{\text {arithmetic }} 3.19$, with $\mathrm{t}_{\text {table }}=1.98$, so $\mathrm{t}_{\text {arithmetic }}>\mathrm{t}_{\text {table }}$, reject $\mathrm{H}_{0}$, meaning that the variable $\mathrm{X}_{1}$ has a positive direct effect on the variable Y. Thus it is proven, that Service Quality has a direct effect on Loyalty.

The analysis results obtained the path coefficient value of $\mathrm{p}_{\mathrm{y} 2}$ of 0.244 and $\mathrm{t}_{\text {count }} 2.90$, with $\mathrm{t}_{\text {table }}=1.98$, so $\mathrm{t}_{\text {count }}$ > $\mathrm{t}_{\text {table }}$, reject $\mathrm{H}_{0}$, meaning that the variable $\mathrm{X}_{2}$ has a positive direct effect on the variable $\mathrm{Y}$. With thus it is proven, that Trust directly influences Loyalty.

The results of the analysis obtained the path coefficient $\mathrm{p}_{\mathrm{y}_{3}}$ of 0.223 and $\mathrm{t}_{\text {arithmetic }} 2.14$, with $\mathrm{t}_{\text {table }}=1.98$, so $\mathrm{t}_{\text {arithmetic }}>\mathrm{t}_{\text {table }}$, reject $\mathrm{H}_{0}$, meaning that the variable $\mathrm{X}_{3}$ has a positive direct effect on the variable $\mathrm{Y}$. With thus it is proven, that Trust directly influences Loyalty.Structurally the path diagram $\mathrm{X}_{1}, \mathrm{X}_{2}$ and $\mathrm{X}_{3}$ to $\mathrm{Y}$ can be seen as in the following figure: 


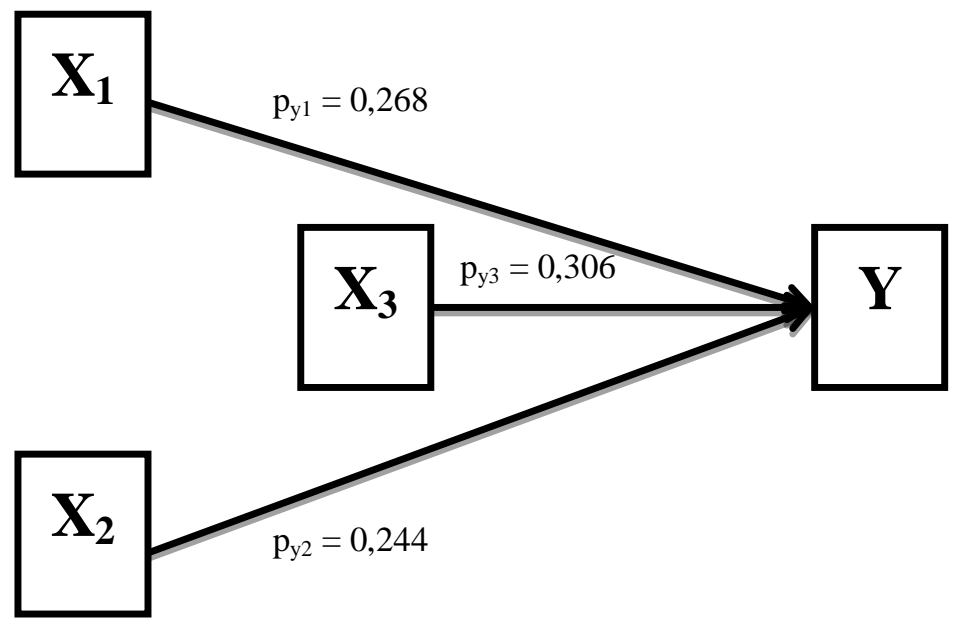

Figure 2:- Structural path coefficient 3.

The direct effect magnitude and significance test for each path ( Path Analysis ) are summarized in the following table.

Table 2:- Summary of the path significance test results.

\begin{tabular}{|c|c|c|c|c|c|c|}
\hline \multirow[t]{2}{*}{ No. } & \multirow{2}{*}{$\begin{array}{l}\text { Influence } \\
\text { Direct }\end{array}$} & \multirow{2}{*}{$\begin{array}{l}\text { Coefficient } \\
\text { pathway }\end{array}$} & \multirow[t]{2}{*}{ df } & \multirow[t]{2}{*}{$\mathbf{T}_{\text {count }}$} & \multicolumn{2}{|l|}{$\mathbf{t}_{\text {tabel }}$} \\
\hline & & & & & $\alpha=0,05$ & $\alpha=0,01$ \\
\hline 1 & $\mathrm{X}_{1}$ with respect to $\mathrm{Y}$ & 0,268 & 115 & 3,19 & 1,98 & 2,62 \\
\hline 2 & $\mathrm{X}_{2}$ with respect to $\mathrm{Y}$ & 0,244 & 115 & 2,90 & 1,98 & 2,62 \\
\hline 3 & $\mathrm{X}_{3}$ with respect to $\mathrm{Y}$ & 0,306 & 115 & 3,72 & 1,98 & 2,62 \\
\hline
\end{tabular}

Structurally the overall path diagram of each structure can be seen in the following figure:

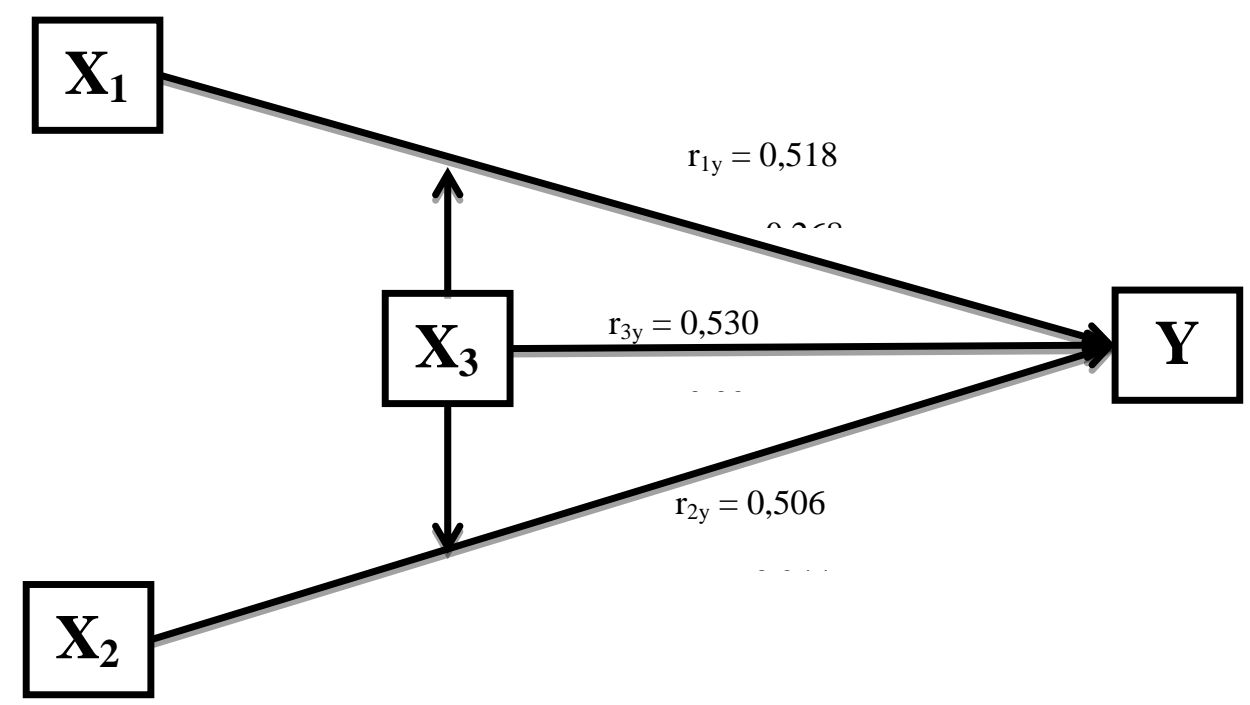

Figure 3:- Causal path diagram of the influence of $\mathrm{X}_{1}, \mathrm{X}_{2}$ and $\mathrm{X}_{3}$ on $\mathrm{Y}$.

Hypothesis test:

Based on the test analysis of the path above, it can be explained the following hypothesis testing:

The first hypothesis: there is a positive direct effect on Service Quality $\left(\mathrm{X}_{1}\right)$ on Loyalty $(\mathrm{Y})$.

The statistical hypothesis tested was a positive direct effect on Service Quality ( $\left.\mathrm{X}_{1}\right)$ on Loyalty (Y)

\section{Statistically:}

$\mathrm{H}_{0}: \beta \mathrm{y}_{1} \leq 0$

$\mathrm{H}_{1}: \beta \mathrm{y}_{1}>0$ 
Based on the results of the path analysis the influence of Service Quality $\left(\mathrm{X}_{1}\right)$ on Loyalty $(\mathrm{Y})$ obtained path coefficient $\rho_{\text {y } 1}$ of 0.268 with $\mathrm{t}_{\text {arithmetic }}=3.19$, while the value of $\mathrm{t}_{\text {table }}=1.98(\alpha=0.05 ; \mathrm{dk}=115)$. Because $\mathrm{t}_{\text {arithmetic }}$ > $\mathrm{T}_{\text {table }}$, then $\mathrm{H}_{0 \text { is }}$ rejected, $\mathrm{H}_{1}$ is accepted. Thus it can be concluded that Service Quality has a direct positive effect on Loyalty

The second hypothesis: there is a positive direct effect on Citra $\left(\mathrm{X}_{2}\right)$ on Loyalty $(\mathrm{Y})$.

The statistical hypothesis tested was a direct positive effect on Institutional Image $\left(\mathrm{X}_{2}\right)$ on teacher task commitment (Y).

Statistically:

$\mathrm{H}_{0}: \beta \mathrm{y}_{2} \leq 0$

$\mathrm{H}_{1}: \beta \mathrm{y}_{2}>0$

Based on the path analysis results of the influence of Institutional Image (X2) on Loyalty (Y) obtained path coefficient $\rho_{\text {y } 2}$ of 0.244 with $t_{\text {arithmetic }}=2.90$, while the value of $t_{\text {table }}=1.98(\alpha=0.05 ; \mathrm{dk}=115)$. Because $t_{\text {arithmetic }}$ > $\mathrm{T}_{\text {table }}$, then $\mathrm{H}_{0}$ is rejected, $\mathrm{H}_{1}$ is accepted. Thus it can be concluded that the Institution's Image has a direct positive effect on Loyalty.

Third Hypothesis: there is a positive direct effect of Trust $\left(\mathrm{X}_{3}\right)$ on Loyalty $(\mathrm{Y})$

The statistical hypothesis tested was a positive direct effect on Trust (X3) on Loyalty (Y).

Statistically:

$\mathrm{H}_{0}: \beta \mathrm{y}_{3} \leq 0$

$\mathrm{H}_{1}: \beta \mathrm{y}_{3}>0$

Based on the results of the path analysis of the influence of Trust (X3) on Loyalty (Y) obtained path coefficient $\rho_{\text {y } 3}$ of 0.306 , with $t_{\text {arithmetic }}=3.72$ while the value of $t_{\text {table }}=1.98(\alpha=0.05 ; \mathrm{dk}=115)$. Because $t_{\text {arithmetic }}>T_{\text {table }}$, then $\mathrm{H}_{0 \text { is }}$ rejected, $\mathrm{H}_{1 \text { is }}$ accepted. Thus it can be concluded that Loyalty has a direct positive effect on Loyalty.

The fourth hypothesis: there is indirect Influence of Service Quality to Loyalty through trust

The constellation of the indirect effect model of Service Quality on Loyalty through Trust is as follows:

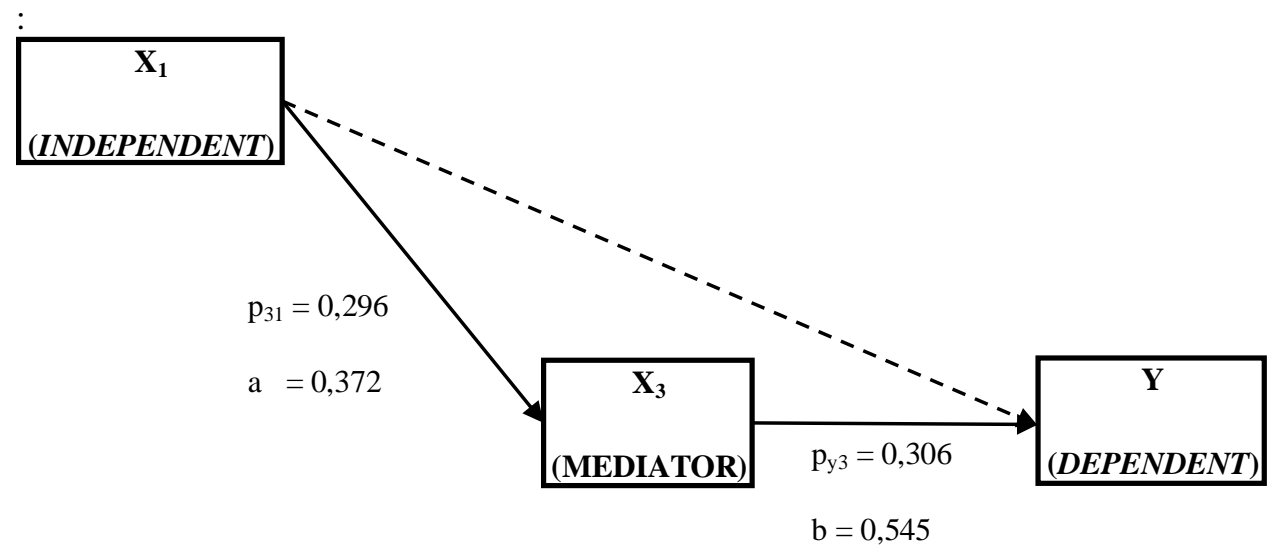

Figure 4:- Constellation of Indirect Effects of $\mathrm{X}_{1}$ on $\mathrm{Y}$ through $\mathrm{X}_{3 .}$

Sobel Test Calculation Calculation:

$\mathrm{a}=0,372$

$\mathrm{b}=0,545$

$\mathrm{Sa}=0,071$

$\mathrm{Sb}=0,080$

$\mathrm{Z}=\frac{\mathrm{a} * \mathrm{~b}}{\sqrt{\mathrm{b}^{2} \mathrm{~S}_{\mathrm{a}}{ }^{2}+\mathrm{a}^{2} \mathrm{~S}_{\mathrm{b}}{ }^{2}}}$ 
$Z=\frac{0,372 * 0,545}{\sqrt{0,545^{2} 0,071^{2}+0,372^{2} 0,080^{2}}}$

$\mathrm{Z}=\frac{0,203}{0,049}=4,153$

The statistical hypothesis tested is the indirect effect of Service Quality $\left(\mathrm{X}_{1}\right)$ on Loyalty $(\mathrm{Y})$ through Trust $\left(\mathrm{X}_{3}\right)$

Ho: $\beta_{31 \times} \beta_{\mathrm{y} 3} \leq 0$

$\mathrm{H} 1: \beta_{31 \times} \beta_{\mathrm{y} 3}>0$

$\mathrm{H}_{0 \text { is }}$ rejected, if $\mathrm{Z}>1.96$.

$\beta_{31 \times} \beta_{\mathrm{y} 3}=(0.296 \times 0.306)=0.091$

Path coefficient (mediation) the indirect effect of $X_{1}$ to $Y$ through $X_{3}$ is $0.091\left(\beta_{31} \beta_{y 3}=0.296 X 0.306\right)$ with a $z$ value (Sobel Test) of . Because the value of $Z$ ( ) is greater than 1.96, it can be concluded that the indirect effect of $\mathrm{X}_{1}$ on $\mathrm{Y}$ through $\mathrm{X}_{3}$ is positive and significant, this can be interpreted that there is an indirect effect of Service Quality on Loyalty through Trust.

The sobel test calculation results are obtained using the online sobel test calculator. The calculation results of the sobel test can be seen in the following figure:

\section{Calculation for the Sobel Test}

An interactive calculation tool for mediation tests

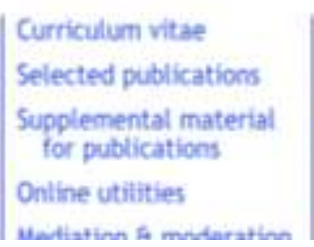

\begin{tabular}{|c|c|c|c|c|}
\hline Input: & & Test statistic: & Std. Error: & p-value: \\
\hline$\Rightarrow 0.372$ & Sobel test: & 4.15318244 & 0.04881558 & 0.00003279 \\
\hline b. 0.545 & Aroian test: & 4.1253502 & 0.04914492 & 0.00003702 \\
\hline$s_{2}, 0.071$ & Goodman test: & 4.18158571 & 0.048484 & 0,00002895 \\
\hline $5,0.080$ & Reset al & & Calculate & \\
\hline
\end{tabular}

The fifth hypothesis: there is an Indirect Effect of Service Quality on Loyalty through Imagery

The constellation of the indirect effect model of Service Quality on Loyalty through Imagery is as follows:

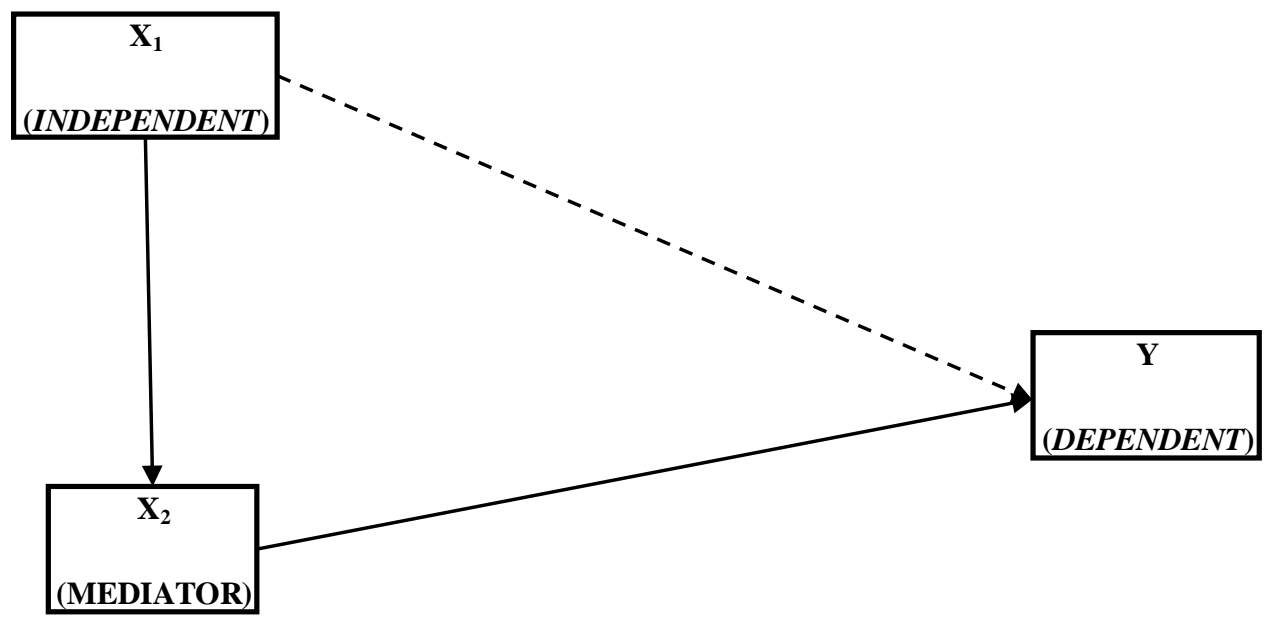

Figure 4.13:- Constellation of Indirect Effects of $\mathrm{X}_{1}$ on $\mathrm{Y}$ through $\mathrm{X}_{2 .}$

Sobel Test Calculation Calculation:

$\mathrm{a}=0,442$

$\mathrm{b}=0,475$

$\mathrm{Sa}=0,075$

$\mathrm{Sb}=0,075$ 
$\mathrm{Z}=\frac{\mathrm{a} * \mathrm{~b}}{\sqrt{\mathrm{b}^{2} \mathrm{~S}_{\mathrm{a}}{ }^{2}+\mathrm{a}^{2} \mathrm{~S}_{\mathrm{b}}{ }^{2}}}$

$\mathrm{Z}=\frac{0,442 * 0,475}{\sqrt{0,475^{2} 0,075^{2}+0,442^{2} 0,075^{2}}}$

$\mathrm{Z}=\frac{0,210}{0,049}=4,314$

The statistical hypothesis tested is the indirect effect of Service Quality $\left(\mathrm{X}_{1}\right)$ on Loyalty $(\mathrm{Y})$ through Institutional Image $\left(\mathrm{X}_{2}\right)$

Ho: $\beta_{21 \times} \beta_{\mathrm{y} 2} \leq 0$

$\mathrm{H} 1: \beta_{21 \times} \beta_{\mathrm{y} 2}>0$

$\mathrm{H}_{0 \text { is }}$ rejected, if $\mathrm{Z}>1.96$.

$\beta_{21 \times} \beta_{\mathrm{y} 2}=(0.476 \times 0.244)=0.116$

Path coefficient (mediation) the indirect effect of $X_{1}$ to $Y$ through $X_{2}$ of $0.116\left(\beta_{21} \beta_{y 2}=0.476 X 0.244\right)$ with a $z$ value (Sobel Test) of Because the value of $Z$ ( ) is greater than 1.96, it can be concluded that the indirect effect of $\mathrm{X}_{1}$ on $\mathrm{Y}$ through $\mathrm{X}_{2}$ is positive and significant. This means that there is a significant indirect effect of Service Quality $\left(\mathrm{X}_{1}\right)$ on Loyalty $(\mathrm{Y})$ through Institutional Image $\left(\mathrm{X}_{2}\right)$

The sobel test calculation results are obtained using the online sobel test calculator. The calculation results of the sobel test can be seen in the following figure:

\section{Calculation for the Sobel Test}

An interactive calculation tool for mediation tests

$\begin{aligned} & \text { Curricutum vitae } \\ & \text { Selected publications } \\ & \text { Supplemental material } \\ & \text { for publications } \\ & \text { Online utilities } \\ & \text { Mertiatinn fit mnderation }\end{aligned} \mid$

\begin{tabular}{|c|c|c|c|c|}
\hline Input: & & Test statistic: & Std. Error: & $p$-value: \\
\hline a 0.442 & Sobel tost: & 4.31438842 & 0.04866275 & 0,000016 \\
\hline b 0.475 & Aroian test: & 4.28585095 & 0.04898677 & 0,0000182 \\
\hline s, 0,075 & Goodman test: & 4.34350363 & 0.04833655 & 0.00001402 \\
\hline$s_{b} 0.075$ & Reset all & & Calculate & \\
\hline
\end{tabular}

The sixth hypothesis: there is an indirect effect of imagery on loyalty through trust

The constellation of the image's indirect effect model on Loyalty through Trust is as follows:

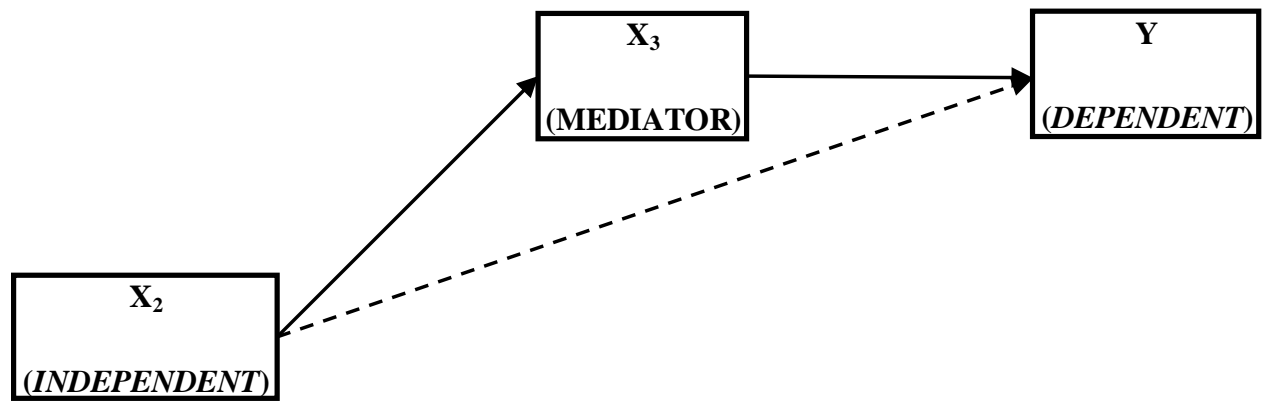

Figure 5:- Constellation of Indirect Effects of $\mathrm{X}_{2}$ on $\mathrm{Y}$ through $\mathrm{X}_{3}$.

Sobel Test Calculation Calculation:

$\mathrm{a}=0,402$

$\mathrm{b}=0,545$

$\mathrm{Sa}=0,076$

$\mathrm{Sb}=0,080$ 
$\mathrm{Z}=\frac{\mathrm{a} * \mathrm{~b}}{\sqrt{\mathrm{b}^{2} \mathrm{~S}_{\mathrm{a}}{ }^{2}+\mathrm{a}^{2} \mathrm{~S}_{\mathrm{b}}{ }^{2}}}$

$\mathrm{Z}=\frac{0,402 * 0,545}{\sqrt{0,545^{2} 0,076^{2}+0,402^{2} 0,080^{2}}}$

$\mathrm{Z}=\frac{0,219}{0,052}=4,178$

The statistical hypothesis tested is that there is an indirect effect of Image $\left(\mathrm{X}_{2}\right)$ on Loyalty $(\mathrm{Y})$ through Trust $\left(\mathrm{X}_{3}\right)$

Ho: $\beta_{32} \times \beta_{\mathrm{y} 3} \leq 0$

H1: $\beta_{32} \times \beta_{\mathrm{y} 3}>0$

$\mathrm{H}_{0}$ ditolak, Jika $\mathrm{Z}>1,96$.

$\beta_{32 \times} \beta_{\mathrm{y} 3}=(0,298 \times 0,306)=0,091$

Path coefficient (mediation) the indirect effect of $\mathrm{X}_{2}$ on $\mathrm{Y}$ through $\mathrm{X} 3$ is $0.091\left(\beta_{32} \beta_{\mathrm{y} 3}=0.2980 .306\right.$ ), with a $\mathrm{z}$ value (Sobel Test) of. Because the value of $Z$ ( ) is greater than 1.96, it can be concluded that the indirect effect of $\mathrm{X}_{2}$ on $\mathrm{Y}$ through $\mathrm{X}_{3}$ is positive and significant. This means that there is a significant indirect effect of Citra on Loyalty through Trust.

The sobel test calculation results are obtained using the online sobel test calculator. The calculation results of the sobel test can be seen in the following figure:

\section{Calculation for the Sobel Test}

An interactive calculation tool for mediation tests

$\left|\begin{array}{l}\text { Curriculum vitae } \\ \text { Selected publications } \\ \text { Supplemental material } \\ \text { for publications } \\ \text { Online utilities } \\ \text { Madiatinn f montaration }\end{array}\right|$

\begin{tabular}{|c|c|c|c|c|}
\hline Input: & & Test statistic: & Std. Error: & p-value: \\
\hline a 0.402 & Sobel test: & 4.17797201 & 0.05243932 & 0.00002941 \\
\hline b 0.545 & Aroian test: & 4.15016997 & 0.05279061 & 0.00003322 \\
\hline$s_{a} 0.076$ & Goodman test: & 4.20634039 & 0.05208566 & 0.00002595 \\
\hline$s_{b} 0.080$ & Reset all & & Calculate & \\
\hline
\end{tabular}

A summary of the six hypotheses can be seen in the following table 3:

Table 4:- Summary of Hypothesis Testing Results.

\begin{tabular}{|c|c|c|c|c|}
\hline Direct Influence & Path coefficient & tcount & t tabel & Test Decision \\
\hline $\mathrm{X} 1$ with respect to $\mathrm{Y}$ & 0.268 & 3.19 & 1.98 & $\begin{array}{l}\mathrm{H} 0 \text { is rejected, } \mathrm{H} 1 \text { is accepted. There is } \\
\text { a positive direct effect of } \mathrm{X} 1 \text { on } \mathrm{Y}\end{array}$ \\
\hline $\mathrm{X} 2$ with respect to $\mathrm{Y}$ & .244 & 2.90 & 1.98 & $\begin{array}{l}\mathrm{H} 0 \text { is rejected, } \mathrm{H} 1 \text { is accepted. There is } \\
\text { a positive direct effect of } \mathrm{X} 2 \text { on } \mathrm{Y}\end{array}$ \\
\hline $\mathrm{X} 3$ with respect to $\mathrm{Y}$ & .223 & 2.14 & 1.98 & $\begin{array}{l}\mathrm{H} 0 \text { is rejected, } \mathrm{H} 1 \text { is accepted. There is } \\
\text { a positive direct effect of } \mathrm{X} 3 \text { on } \mathrm{Y}\end{array}$ \\
\hline Indirect Influence & Path coefficient & Z sobel & $\begin{array}{l}\mathrm{Z} \\
\text { (critical ratio) }\end{array}$ & Test Decision \\
\hline $\begin{array}{l}\mathrm{X} 1 \text { against } \mathrm{Y} \text { through } \\
\mathrm{X} 3\end{array}$ & 0.091 & 4,153 & 1.96 & $\begin{array}{l}\mathrm{H} 0 \text { is rejected, } \mathrm{H} 1 \text { is accepted. There is } \\
\text { a positive direct effect of } \mathrm{X} 1 \text { on } \mathrm{Y} \\
\text { through } \mathrm{X} 3\end{array}$ \\
\hline $\begin{array}{l}\mathrm{X} 1 \text { with respect to } \mathrm{Y} \\
\text { through } \mathrm{X} 2\end{array}$ & .116 & 4,314 & 1.96 & $\begin{array}{l}\mathrm{H} 0 \text { is rejected, } \mathrm{H} 1 \text { is accepted. There is } \\
\text { a positive direct effect of } \mathrm{X} 1 \text { on } \mathrm{Y} \\
\text { through } \mathrm{X} 2\end{array}$ \\
\hline $\begin{array}{l}\mathrm{X} 2 \text { with respect to } \mathrm{Y} \\
\text { through } \mathrm{X} 3\end{array}$ & 0.091 & 4,178 & 1.96 & $\begin{array}{l}\mathrm{H} 0 \text { is rejected, } \mathrm{H} 1 \text { is accepted. There is } \\
\text { a positive direct effect of } \mathrm{X} 2 \text { on } \mathrm{Y} \\
\text { through } \mathrm{X} 3\end{array}$ \\
\hline
\end{tabular}




\section{Conclusion:-}

Based on the results of research and the results of data analysis that has been described, then the conclusions can be obtained as follows:

1. There is a positive direct effect on service quality on loyalty, meaning that the level of quality is determined by the quality of service. The better the quality of service, the higher.

2. There is a positive direct effect on the image of loyalty, meaning that student loyalty will increase depending on the image of an institution, the better the image of the Tri Dharma Widya School of Economics then the higher the level of student loyalty.

3. There is a positive direct effect of trust on loyalty, meaning that the level of trust will affect loyalty. The higher the level of trust the higher the loyalty.

4. There is an indirect effect of service quality on loyalty through trust. It was concluded that trust can mediate the relationship of service quality with loyalty. This is to be able to increase loyalty, the quality of service increases trust first before increasing loyalty.

5. There is an indirect effect of the image on loyalty through trust. It was concluded that trust can mediate the relationship of image to loyalty. This is to be able to increase loyalty, then the image increases trust first before increasing loyalty.

6. There is an indirect effect of service quality on loyalty through image. It was concluded that the image can mediate the relationship of service quality with service quality. This is to be able to increase loyalty, then the quality of service improves the image first before increasing loyalty.

\section{Acknowledgments:-}

The researcher realizes that this dissertation can be completed thanks to the support and assistance from various parties. Therefore the researcher would like to express his gratitude and highest appreciation to:

1. Dr. Komarudin, M.Si Rector of Jakarta State University.

2. Prof. Dr. Nadiroh, M.Pd. as I Director of the Jakarta State University Postgraduate Program.

3. Dr. Suryadi as Chair of the Postgraduate Education Study Program, Jakarta State University.

4. Prof. Dr. Bedjo Sujanto, M.Pd. as the Promoter who has been willing to provide time and provide guidance and advice for the completion of this Dissertation.

5. Prof. Dr. Eliana Sari, MM as Co Promoter who has been willing to provide time and provide guidance and advice for the completion of this Dissertation.

6. Drs. H. Andi Anwar Parenrengi, SH, chairman of the LPI and TDW foundation who has facilitated and supported researchers in completing this dissertation.

7. Mascik HS's beloved mother for all her prayers and support to researchers so that this dissertation can be completed.

8. All lecturers who have guided and taught their knowledge to researchers and administrative staff who have provided various facilities in pursuing education in the Jakarta State University Postgraduate Education Study Program.

\section{References:-}

1. Ahmad, N. H., Ramayah, T., Halim, H. A., \& Rahman, S. A. (2017). Handbook of research on small and medium enterprises in developing countries. Handbook of Research on Small and Medium Enterprises in Developing Countries. New York: IGI Global. https://doi.org/10.4018/978-1-5225-2165-5.

2. Alma, B. (2014). Menejemen Pemasaran dan Pemasaran Jasa. Bandung: Alfabeta.

3. Annamdevula, S., \& Bellamkonda, R. S. (2016). The effects of service quality on student loyalty: the mediating role of student satisfaction. Journal of Modelling in Management, 11(2), 446-462. https://doi.org/10.1108/JM204-2014-0031

4. Christopher H. Lovelock, J. W. \& P. C. (2012). Essentials of Service Marketing, 2nd Edition. Singapore: Pearson Education Published.

5. Clark, F. . (1992). Quality and service: A Key focus for performance in the public sector (Working paper series HWP $11 / 92$ No. 11/92).

6. Davis, D. L. G. \& S. B. (2010). Quality Management for Organizational Excellent Introduction to Total Quality 6 th edition. New Jersey: Pearson Prentice Hall.

7. Doney, P. M., \& Cannon, J. P. (1997). An examination of the nature of trust in buyer-seller relationships. Journal of Marketing, 61(2), 35-51. https://doi.org/10.2307/1251829

8. Fombrun, C. B. M. van R. and C. J. (2007). Essential of Copporate Communications. USA: Tylor and Francis. 
9. Goodman, J. A. (2015). Strategic Customer Service. New York: Amacom.

10. Grigoroudis, E., \& Siskos, Y. (2010). Customer Satisfaction Evaluation, Springer, New York. New York: Springer Businnes Media.

11. Gronroos, C. (2001). The perceived service quality concept ??? a mistake? Managing Service Quality: An International Journal, 11(3), 150-152. https:// doi.org/ 10.1108/09604520110393386

12. Laudon, K. C. L. \& J. P. (2012). Management Information Systems. England: Pearson Education Limited.

13. Leonard, Mc. (Usyd) et. a. (2013). The Loyalty Model of Privatt University Student Stduy Case: STIKOM London School of Public Relation. 29 th Desember 2013, Vol.20 No. 1,. Internasional Jurnal of Information Technology and Business Management, 1(2), 78.

14. Minor, J. C. M. dan M. (2002). Perilaku Konsumen. Jakarta: Erlangga.

15. Ramsey, F. F. R. dan S. M. (1988). Managing Relationship and Building Loyality. England: Prentice Hall. 